\title{
Foreword
}

\section{Strategic Grazing Management for Complex Creative Systems}

\author{
By Matt Barnes and Ann Hild \\ Editors for Sponsored Issue
}

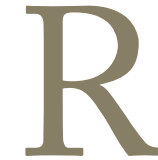

angelands are complex systems because the dynamic relationships between their parts result in self-organization, emergent properties, and unpredictable behavior. This panarchy of nested adaptive cycles ${ }^{1}$ that oscillate between order and chaos is what many land managers call "the real world." Considerable debate in the rangeland profession, and especially within the ranching community, surrounds our notions of the efficacy of planned grazing management to achieve plant community, livestock production, and profitability goals. A variety of rotational deferment, rest, and grazing approaches have been promoted and applied by managers from geographically disparate regions. Rotational grazing (a single herd moved through multiple paddocks) in particular has been applied in many variations (e.g., rational, high-intensity/low-frequency, short-duration, time-control, management-intensive, or cell grazing). Often rotations are installed on a rigid calendar basis, sometimes adapted to unique on-site conditions. ${ }^{2-4}$

It is ironic that the phrase grazing "system" as popularly used tends to imply rigid application - the polar opposite of the word's meaning in systems theory. Such grazing "systems" can be simple or complicated solutions to complex problems. Studies that compare grazing "systems" are inconsistent, and most have found little or no advantage of rotational over continuous grazing. Particularly disappointing to managers who use rotational grazing is the apparent inability to document differences in plant growth and recovery or animal production, particularly in more arid environments. The lack of clear advantages of rotational grazing is especially apparent when pastures are small and lack plant species diversity. We have come to realize that it is especially hard to demonstrate the impacts of any grazing "system" when animal movements are applied on a rigid schedule for the sake of scientific rigor, a common conclusion of recent scientific literature..$^{5-7}$

And yet, substantial evidence is documented in scientific ${ }^{8,9}$ and case studies, ${ }^{10,11}$ and the practical experience of individual ranchers, ${ }^{12,13}$ indicating that strategic grazing management-if well-planned and adaptively managed - can have profound effects on the landscape, animal production, and ranch eco- nomics on individual landscapes. The discrepancy has been noted by scientists who suggest that our profession must do a better job of documenting range management at the landscape scale, identifying and recording the variety of factors associated with adaptive decision-making, and consider a less controlled approach to studying comparisons of grazing "systems." ${ }^{\text {-10 }}$ Our classic approach to range science is still effective in isolating individual portions of ecosystems, but practical experience within the context of complexity has shown that researchers and managers must expand our frames of reference. The papers within this sponsored issue are intended to move the profession beyond debate as suggested by Brown and Kothmann in $2009^{14}$ and Briske et al. in 2011. ${ }^{15}$

\section{What is Included in This Issue}

This issue of Rangelands provides a tangible outcome of ideas originating from the 2008 symposium Strategy vs. System: Grazing for Desired Outcomes, held by the Colorado Section of the Society for Range Management in Fort Collins, Colorado, and more fully developed in presentations at Strategic Grazing Management for Complex Adaptive Systems at Colorado State University in 2012. ${ }^{\mathrm{i}}$ Our intent in the 2012 symposium and this issue is to synthesize the emerging ideas and resolve some of the lingering questions from the 2008 symposium. The papers presented here place scientific and case studies into a framework of complex systems. ${ }^{15}$ Our intent is not to ask "Is rotational grazing better than other forms of grazing management?" Instead, the papers included here inform our perceptions of the complexity of grazing management by considering how to strategically adapt animal movement and management to the inherent complexity of endlessly changing ecological systems and their underlying processes. Partly inspired by the book Resilience Thinking, ${ }^{1}$ the issue pairs scientific theory with corroborating first-person case studies of strategic management to identify some emerging principles of strategic grazing decisions. Often, the reader will find specific tactics that have

'Presentations from the 2012 symposium are available online at: http:// www.rangelands.org/strategicgrazing/ 
been developed by creative managers as they adapt to changing conditions at landscape scales.

\section{Emerging Principles}

Effective management of grazing is based on four approaches: 1) matching the stocking rate to the resource and the animal needs, 2) timing the frequency and duration of grazing and recovery periods to the resource constraints, 3 ) distributing animal use spatially to provide a diversity of plant offerings, and 4) moderating selection of those plants by grazing animals. What is new in applying these principles within rangeland landscapes is the need to reconcile them with perceptions of ecosystems as complex systems that continually respond and are transformed within a dynamic world. In this issue, Provenza et al. explain how we must change our thinking and worldview from pursuit of grazing prescriptions to management that is a process of continual response to dynamic, everchanging assemblages of life forms. The idea that we cannot use the same response for grazing in different landscapes is an important one: we must look for commonalities in the process of responding to dynamic systems, rather than trying to identify truisms and "rules of thumb" that should guide grazing management everywhere. A key component of creative, strategic management is the need to continually assess the ecosystem process response to current management actions in order to adapt future management such that we continue to approximate future desired trajectories. In this way, managers and all organisms actively participate in creating new conditions of the future-some of them unanticipated. It is this creative element that we see being documented for the first time by managers in the case studies that follow. Provenza et al. also illuminate the relationship between science and management, suggesting that we all (scientists and managers) must "rekindle our relationships with one another and with the landscapes we inhabit."

Frasier and Steffens (this issue) describe an economic optimum stocking rate that is dependent on the ratio of variable costs to the value of production-one that is independent of fixed (overhead) costs. Although many managers are faced with the reality of economic risk associated with not covering fixed costs, it is important for managers to separate considerations of fixed costs from stocking rate decisions. Many examples demonstrate how confusing stocking rate decisions with considerations of overhead can lead to judgments that do not resolve profit issues. Rangelands are inherently variable and notorious for limited and unpredictable rainfall. For practitioners, stocking rates are not prescriptive simply because of the difficulty of managing for wide temporal variability. It is clear that resource productivity is not only a moving target, but a form of history that never exactly repeats itself in the same way on a particular landscape. Managers understand that relying on average precipitation, for example, is an ineffective approach. Ortega et al. (this issue) provide south Texas examples of stocking rate adjustments to accommodate the commonness of very dry and very wet years.
A survey of the 139 attendees at the 2012 symposium, with a $52 \%$ response rate, found that most respondents felt that the symposium had "resolved the old debate" $(63 \%)$ and had "moved the discussion beyond the old debate" (90\%). Most said that they would apply the information on their ranches or in the grazing operations of ranches with which they worked (89\%) and an overwhelming majority said that the presentations should be published, either online/open-access or in Rangelands (97\%).

Steffens et al. (this issue) describe grazing management in the context of timing that is driven by dynamic processes of plant recovery. They recognize that managers must provide recovery periods free from defoliation to prevent degradation from severe defoliation of preferred plants. Adequate periods are judged by the full recovery of photosynthetic capacity of plants within preferred use areas. Grazing managers then must provide recovery periods, which coincide with growth of desired plants, for positive plant community changes to occur. Recovery periods must often approach or exceed a full growing season to accomplish that physiological target. Grissom and Steffens (this issue) offer examples from the plains of eastern Colorado that document the results of inadequate and adequate recovery periods. They emphasize the critical need to plan for the seasonal variation in the relative palatability of cool- and warm-season plants.

Uneven spatial distribution of animals on the landscape has been addressed in many research studies. Managers recognize that animal distribution on extensive rangeland landscapes presents issues of scale, which have caused researchers to overlook some potential outcomes of managing animal movement (see Norton et al., this issue). Although it is clear that distribution of grazing animals is shifted by creating smaller paddocks, the interaction of animal behavior with higher stocking densities is a complex response that depends on the mixture and array of plant species on the landscape. One of the greatest challenges in range management today (for both scientists and managers) is understanding the interactions of animal behavior with the diversity of resources on variable and disparate landscapes. In the southern Rocky Mountains of western Colorado, an example of planned grazing uses multiple paddocks to target more spatially even distribution of grazing between formerly heavily grazed preferred areas and previously little-used steep slopes (see Barnes and Howell, this issue). They suggest that actual availability of forage to animals, and thus grazing capacity, are enhanced with use of steep areas at the Howell Ranch.

The experience of seasoned managers is nowhere better demonstrated than in the art of understanding the influence of higher stocking densities on specific landscapes where the mixture and response of plant species have been observed over very long times. Peterson et al. (this issue) present a viewpoint based on many years of experience, giving us the chance to observe the thinking behind increased stocking densities. The responses they see in tall-grass pasture in Missouri are 
dependent on the species present, the rainfall timing and intensity, and the very nature of the "lay" of the landscape itself. This viewpoint paper, although specific to a relatively moist, productive, and diverse area, is an example of the complexity of decisions that all rangeland managers face. They have found that stocking density can be a powerful tool to manage grazing land resources.

What are the contributions of this issue to the range management profession? We believe that the papers demonstrate new ways of perceiving rangelands and are honest attempts to document aspects of "experiential knowledge" that are seldom reported in journals. First, readers should not look for rules or recipes for success. It is clear in these pages that results of grazing management depend greatly on the resource used, the constraints that shift with geographic location, the scale of the units, and the unique history from which each example is derived. Second, we hope that readers see the issue as an honest attempt of authors to record some of the considerations that managers address in adapting their grazing management-an aspect lacking in the literature elsewhere. ${ }^{6,715}$ There are creative (and sometimes conflicting) responses to dynamic ecosystems that are used to address encounters with unique and volatile sequences of events. Rangelands are a product of their history, but not especially predictable because of it. We are challenged to hold the reins lightly at times, take them with force on some occasions, and sometimes just drop them and hold on! While our science has worked hard to record how to tell these times apart, managers are out there continually shifting between these approaches to point rangelands onto a resilient trajectory. Both paths provide vital ways forward and we can all learn by uniting them.

\section{Acknowledgments}

Tim Steffens was instrumental in initiating the collaborative efforts that culminated in this issue and Matt Barnes took the lead on paper submission and author support and encouragement throughout the review process. Our sponsors, especially the Colorado Section of the Society for Range Management, supported the symposia and provided funding for this issue. Editor Lori Hidinger and Associate Editor Ann Hild coordinated the review process, and the many reviewers significantly improved all of the manuscripts.

\section{References}

1. Walker, B.H., And D. Salt. 2006. Resilience thinking: sustaining ecosystems and people in a changing world. Washington, DC, USA: Island Press. 174 p.

2. Voisin, A. 1959. Grass productivity. London, United Kingdom: Crosby, Lockwood, and Sons Ltd. 353 p.

3. Goodloe, S. 1969. Short duration grazing in Rhodesia. Journal of Range Management 22:369-373.

4. Savory, A., and J. Butterfield. 1999. Holistic management: a new framework for decision making. Washington, DC, USA: Island Press. 616 p.
5. Holecheк, J. L., H. Gomes, F. Molinar, D. Galt, and R. VALDEZ. 2000. Short duration grazing: the facts in 1999. Rangelands 22(1):18-22.

6. Briske, D., J. Derner, J. Brown, S. Fuhlendorf, R. Teague, B. Gillen, A. Ash, K. Havstad, and W. Willms. 2008. Benefits of rotational grazing on rangelands: an evaluation of the experimental evidence. Rangeland Ecology \& Management 61:3-17.

7. Briske, D. D., J. D. Derner, D. G. Milchunas, and K. W. TAтE. 2011. An evidence-based assessment of prescribed grazing practices. In: D. D. Briske [ED.]. Conservation benefits of rangeland practices: assessment, recommendations, and knowledge gaps. Washington, DC, USA: USDA Natural Resources Conservation Service. p. 21-74 8.

8. Norton, B. E. 1998. The application of grazing management to increase sustainable livestock production. Animal Production in Australia 22:15-26.

9. Teague, R., F. Provenza, U. Kreuter, T. Steffens, and M. BARnes. 2013. Multi-paddock grazing on rangelands: why the perceptual dichotomy between research results and rancher experience. Journal of Environmental Management 128:699-717.

10. Stinner, D. H., B. R. Stinner, and E. Martsolf. 1997. Biodiversity as an organizing principle in agroecosystem management: case studies of holistic resource management practitioners in the USA. Agriculture Ecosystems E Environment 62:199-213.

11. Teague, W. R., S. L. Dowhower, S. A. Baker, N. Haile, P. B. DeLaune, and D. M. Conover. 2011. Grazing management impacts on vegetation, soil biota, and chemical, physical and hydrological properties in tall grass prairie. Agriculture Ecosystems E Environment 137:113-123.

12. SAYre, N.F. 2000. The new ranch handbook: a guide to restoring Western rangelands. Santa Fe, NM, USA: Quivira Coalition. 102 p.

13. White, C. 2008. Revolution on the range: the rise of a new ranch in the American West. Washington, DC, USA: Island Press. 248 p.

14. Brown, J., and M. Кothmann. 2009. Rotational grazing on rangelands: synthesis and recommendations. Rangelands 31(5):37-38.

15. Briske, D. D., N. F. Sayre, L. Huntsinger, M. FernandezGimenez, B. Budd, and J. D. Derner. 2011. Origin, persistence, and resolution of the rotational grazing debate: integrating human dimensions into rangeland research. Rangeland Ecology E Management 64:325-334.

Authors are Owner and Rangeland Consultant, Shining Horizons Land Management, LLC, and Field Director for Rangeland Stewardship, Keystone Conservation, Bozeman, MT 59771, USA, Matt@ShiningHorizons.com (Barnes); and Associate Professor, Dept of Renerwable Resources, University of Wyoming, Laramie, WY 82071 (Hild). Barnes is also President (2013), Colorado Section SRM.

Rangelands 35(5):3-5

doi: 10.2111/RANGELANDS-D-13-00052.1

(c) 2013 The Society for Range Management 